\title{
Fichte's Normative Ethics: Deontological or Teleological?
}

\author{
OWEN WARE \\ University of Toronto \\ owen.ware@utoronto.ca
}

\begin{abstract}
One of the most controversial issues in recent studies of Fichte concerns the status of his normative ethics, that is, his theory of what makes actions morally good or bad. Scholars are divided over Fichte's view regarding the 'final end' of moral striving, since it appears this end can be either a specific goal permitting maximizing calculations (the consequentialist reading defended by Kosch 2015), or an indeterminate goal permitting only duty-based decisions (the deontological reading defended by Wood 2016). While I think both interpretive positions contain an element of truth, my aim in this paper is to defend a third alternative, according to which Fichte's normative ethics presents us with a unique form of social perfectionism.
\end{abstract}

All the individuals who belong to the human race are different. There is only one thing in which they are in complete agreement: their ultimate goal perfection. (Fichte, VBG 6:309-10)

\section{Introduction}

What, according to J.G. Fichte, makes an action morally correct?

In the System of Ethics, his answer seems to be, first, that the action must harmonize with our own conscience (the inner condition of morality) and, second, that it must harmonize with our shared moral end (the outer condition of legality). That the two conditions come apart explains an intuition many of us feel, namely, that in principle we can do the right thing while acting from the wrong motive, or the wrong thing while acting from the right motive. For many years, however, scholars ignored this distinction in Fichte's theory and assigned to him the view that one's conscience by itself offers infallible guidance in fulfilling the outer condition of moral correctness. Yet this is a misreading in my view, and it has recently 
been challenged by a number of commentators, including Allen Wood in Fichte's Ethical Thought (2016). ${ }^{1}$

Once we abandon this misreading, we face a difficult interpretive question. How can we fulfil the outer condition and act in ways that harmonize with our shared moral end if not by following the feelings of our conscience as diligently as we can? One possibility is that we first specify a notion of our shared moral end, and then evaluate the correctness of our actions in light of how well they promote its realization. This would commit Fichte to a broadly teleological view of moral evaluation, since it would fix the outer condition to an objective state of affairs we are striving to attain. Later in this paper I want to suggest that the teleological view gets something right about Fichte's ethics, but only if we properly distinguish an ordinary perspective on morality from a philosophical one. I say this now in order to distance my position from a reading defended in several articles by Michelle Kosch, according to which Fichte's view of practical reasoning is consequentialist in form $(2014 ;$ 2015). In Wood's assessment, with which I agree, Kosch's consequentialist reading faces serious problems. But in my discussion to follow I want to propose that we can avoid these problems while still understanding Fichte as someone for whom our duties are teleologically structured. I also want to propose that this account is able to accommodate the deontological elements we find in his theory, without going so far as to say, as Wood puts it, that Fichte is 'radically committed to deontology' (2016, p. 149).

In defending these views, I want to remain true to the spirit of Fichte's Ethical Thought, at least in two ways. First, a central theme of the book is that Fichte does not fit neatly into any particular philosophical category. His transcendental idealism, for example, is neither straightforwardly metaphysical nor anti-metaphysical (as Wood argues in Chapter 2). His metaethics, to take another example, is neither straightforwardly realist nor anti-realist (as Wood argues in Chapter 4). By characterizing Fichte's normative ethics as a combination of deontological and teleological elements, my intention is to build upon, rather than to reject, this line of interpretation. Secondly, Wood himself is sensitive to the teleological character of Fichte's ethics, and he even acknowledges the importance of 'perfection' as a concept within his system. To this extent, the alternative account I wish to put forward will draw upon material Wood discusses openly. My main criticism is that Wood goes too far in resisting a

\footnotetext{
${ }^{1}$ See also Kosch (2014) and Ware (2016).
} 
consequentialist reading of Fichte, so much so that he commits himself to the view that our shared moral end is beyond any specification at all. As we shall see, Fichte does permit us to articulate the end of our moral striving - enough, in my view, to support a non-deontological view of our duties. I believe the best label we have for this view is perfectionism, but I should say from the outset that I have no particular attachment to this term, and like Wood, I believe it is a virtue of Fichte's thought that it resists normal categorization.

\section{The consequentialist reading}

Disagreement over the identity of Fichte's ethics is largely due to the fact that Fichte is unclear about what he means by our 'final moral end'. Quite often he speaks of this end in terms of our striving for 'independence' (Unabhängigkeit) and 'self-sufficiency' (Selbständigkeit), but these descriptions tend to be unhelpfully vague. Our striving, he says, aims at 'absolute indeterminability through anything outside itself' ( $S L$ 4:29), or the independence and self-sufficiency of our 'entire being' ( $S L$ 4:209). Even more mysteriously, Fichte describes our final end in terms of 'merging' with the infinite, and at times he relates this goal to the unio mystica tradition: 'The error of the mystics', he tells us, 'is that they represent the infinite, which cannot be attained in any time, as something that can be attained in time. The complete annihilation of the individual and the fusion of the latter into the absolutely pure form of reason or into God is indeed the ultimate goal of finite reason; but this is not possible in any time' (SL 4:151). On the few occasions where Fichte gives us more concrete details about this ultimate goal, his descriptions are almost always counterintuitive, as when he writes that the 'world must become for me what my body is' in pursuing my ethical vocation ( $S L$ 4:229). Given remarks like this, it is understandable why Fichte's theory has elicited a charge of 'philosophical mystification', even among his more sympathetic readers. ${ }^{3}$

It is also understandable why some commentators have turned to Fichte's popular works to find clues as to what he might have in mind by our final end. One noteworthy passage appears in the Vocation of Humankind (1800), which offers a Stoic account of how striving for self-sufficiency involves our gradual dominance over the natural environment, specifically through the advancement of science and

\footnotetext{
${ }^{2}$ See, for instance, Schopenhauer (2009 [1841], p. 180).

${ }^{3}$ See, for instance, Neuhouser (1990, pp. 141-2).
} 
technology. There Fichte depicts the condition of humankind in terms of a struggle against 'recalcitrant nature', in which 'floods, storms, and volcanoes desolate whole countries', in which human works are tossed into 'wild chaos', and in which diseases 'sweep people into an untimely grave' ( $B M$ 1:82). Dialling his rhetoric even higher, Fichte goes on to say that such 'outbreaks of raw violence before which human strength dwindles to nothing [...] are nothing other than the last convulsive strokes in the formation of our planet, which is now reaching completion' ( $B M$ 1:82). It shall come to pass that nature enters into a stable condition, 'which allows one to calculate and reckon safely on its regular pace, and which keeps its force steady in a definite relation with the power destined to control it - the power of humankind' ( $B M$ 1:82). The achievement of this power shall be possible, Fichte concludes, by careful investigation into nature's laws, so that we may in time 'survey the whole power of this nature, and learn to calculate its possible developments' ( $B M$ 1:82).

Not surprisingly, the attitude expressed in these remarks has failed to inspire many of Fichte's readers. Samuel Coleridge thought it reduced his philosophy to a 'boastful and hyperstoic hostility to Nature as lifeless, godless, and altogether unholy' (1884 [1817], pp. 260-1), and Hegel took it as further evidence that Fichte, like Kant before him, had 'mishandled' the sphere of nature by opposing it to the sphere of rationality (1977 [1801], p. 83). In recent work, however, Kosch has argued that the Vocation essay provides us with useful material for filling in the content of our final end. As she points out, once we get past Fichte's dramatic talk of 'floods, storms, and volcanoes', the claim that our final end consists of control is neither vague nor mystical. It may be summarized as follows:

Control: Our progress toward the final end of self-sufficiency is progress toward a state of affairs in which we have acquired control over nature.

As Kosch explains, the basic thought is that progress toward our final end is really 'progress toward a situation in which nature's "lawless violence" has been mastered, rendered predictable and non-threatening by scientific insight into natural laws, and in which technology buttresses human powers' (2015, p. 357). On this reading, we can say that if the moral law demands our 'complete liberation' from all external limitations, then our ethical vocation must involve acquiring 
dominion over those aspects of nature which threaten our capacity for rational planning and deliberation. ${ }^{4}$

Now if this is right - that is, if we can specify our final end in terms of Control - then we are but a step away from the consequentialist reading Kosch finds attractive. All we need to do is connect the concept of our final end, understood as a form of mastery over the sensible world, with the outer condition of moral correctness discussed above. The result is that we can calculate an action's goodness, objectively speaking, relative to how well its consequences maximize our attainment of this control. To this extent, the form of Fichte's ethics would be no different from the hedonistic utilitarianism of Bentham or the non-hedonistic utilitarianism of Mill: in each case we have a teleological moral principle, which prescribes the production of an end (maximal pleasure, maximal utility, or maximal control), against which we can then evaluate an action's goodness on the basis of its tendency to promote this end. What makes Fichte's theory different from classical utilitarianism is simply that it identifies our final end, not with the value of welfare (private or public), but with the value of rational agency as such. As Kosch puts it, the end of our independence and self-sufficiency is the 'end of broadening the scope of possible rational plans of action, by increasing our ability to ensure that our plans are carried out if we undertake them, and by opening up novel possibilities for planning through innovation and creativity in ways of living, producing, and interacting' (2015, p. 358, emphasis in original).

\section{Leaving consequentialism behind}

As I mentioned, Wood is highly critical of the consequentialist reading. ${ }^{5}$ But what reasons does he have for rejecting it? And why does he think the deontological reading fares any better? To begin with, Wood devotes portions of Chapters 5 and 6 to explaining what he sees as major shortcomings of Kosch's account, and from this material I

\footnotetext{
${ }^{4}$ In Kosch's view 'progress toward material independence or self-sufficiency is depicted (in part) as progress away from a situation in which the species must struggle for survival "against recalcitrant nature"' (2015, p. 357). Citing this passage, Wood expresses puzzlement over the 'in part' qualification: 'She does not explain what else she thinks absolute self-sufficiency would involve [...] But in her further interpretation of Fichte's ethics, Kosch seems to treat maximal control as simply identical with the end of absolute self-sufficiency' (2016, p. 148, emphasis in original). I think there is room to reconstruct Kosch's view in terms of independence rather than control - but even this reconstruction will face difficulties, as we shall see below.

${ }^{5}$ See Wood (2007) for his general critique of consequentialism as a moral theory.
} 
would like to focus on two of his key objections. In overview, they are: (1) that pursuing dominion over nature is not a candidate for Fichte's 'final end'; and (2) that the goal of absolute self-sufficiency is too indeterminate to factor into any kind of teleological ethics, including consequentialism. Looking ahead, I believe the first objection is correct, but in my view the second gets Wood into trouble.

\subsection{First objection: control over nature}

Like Wood, I believe that, for various textual reasons, Control is illsuited to play the role of a final end. First, the portrayal of nature as a 'violent' or 'recalcitrant' force is nowhere to be found in the System of Ethics. ${ }^{6}$ On the contrary, Fichte argues explicitly in this work that to understand the natural drive within us we must first understand the system of nature in general as a 'real organic whole' - that is, as a system in which each individual part of nature stands in a relation of reciprocal determination with the whole of nature (SL 4:119, emphasis in original). ${ }^{7}$ This leads him to the striking claim that what we call the 'drive to self-preservation' is really a drive to unify all the various parts of nature within us, to preserve ourselves as real organic wholes. And this same drive for unity and wholeness, Fichte goes on to say, is what animates the larger network of nature outside us, the 'whole of wholes' of which we are in turn parts: 'Here there is everywhere harmony, reciprocal interaction, and not, as it were, mere mechanism' ( $S L$ 4:124; cf. GNR 3:78). All this supports Wood's insight that we 'misunderstand Fichte's ethics if we take it to be about the superiority or dominance of the rational over the natural, or the pure over the empirical' (2016, p. 157). Fichte's ethics is 'fundamentally about harmony, unity, or wholeness' (Wood 2016, p. 157, emphasis in original) ${ }^{8}-$ and the same is true, I would add, with respect to his view of nature.

\footnotetext{
${ }^{6}$ We should also bear in mind what Fichte says in the Preface to the Vocation essay: 'that the "I" who speaks in the book is by no means the author' ( $B M$ 1:1). Much like the first-person voice in Descartes' Meditations, the first-person voice in the Vocation essay represents a progressive narrative of philosophical discovery, one which the reader can enter into and follow. This lends evidence to the idea that the dominating and controlling view toward nature we find in Fichte's essay is, not his own view, but the viewpoint of a specific (and by no means final) dialectical stage of insight.
}

${ }^{7}$ Elsewhere Fichte describes the body in similar terms: 'the body is a product of nature and consists of parts, which constitute this determinate whole only in their union with one another; therefore, nature contains within itself the law that its parts must necessarily unite to form wholes, which, in turn, constitute one single whole. Nature is both organized and organizing' (WLnm $[K] \$ 19$ ).

${ }^{8}$ This claim is also central to Breazeale's (2013) reading of Fichte. 
Secondly, even if we wish to use Kosch's strategy of finding clues in the Vocation essay, it is not evident why the passage on humanity's struggle with nature should take priority. Fichte is quite clear that the real problems we must countenance lie elsewhere: '[I]t is not nature', he writes, 'it is freedom itself which causes most of the disorders and the most terrible ones among humanity. Humankind's most cruel enemy is humankind' (BM 1:84-83, emphasis added). In the pages to follow he gives accounts of the disorders humanity brings upon itself, and one of the examples even draws a link between technology and war: 'Equipped with the greatest inventions of the human mind navies ply the oceans. Men press through storm and wave in search of other men on the lonely, inhospitable expanse. They find them and defy the rage of the elements so as to be able to destroy them with their own hands' ( $B M$ 1:83). Granted, Fichte does not go so far as to assert (as members of the Frankfurt school would later write) that ' $[w]$ hat human beings seek to learn from nature is how to use it to dominate wholly both it and human beings' - but the idea is not far from the surface. Fichte is sensitive to the complex phenomenon of humanity's will to dominate, which he describes in connection to evil as a 'blind drive to make our lawless will reign everywhere' (SL 4:194).

Wood is aware of this connection as well. To value mastery over the natural environment for its own sake, he observes, 'would amount to the supremely evil maxim of "seeking unrestricted and lawless dominion over everything outside us"” (2016, p. 153; cf. p. 156). And he thinks Kosch's formula of our final end carries this undesirable implication. But in fairness to Kosch, Fichte does say things in the System of Ethics that give prima facie support to her reading. In one place he writes, for example, that the 'final end of all the actions of any morally good human being, and especially of all the external effects of his actions, can be summarized in the following formula: he wills that reason and reason alone rule [herrsche] in the sensible world' (SL 4:275, emphasis in original). But when we read the surrounding text carefully, it is clear that Fichte is speaking of 'rule', not in the sense of domination, but in the sense of authority, and the proper object of this authority, he explains, is the entire community of rational beings: 'Reason, however, can have dominion only in and through rational beings. Hence moral acting, even if it is perhaps aimed directly at nonrational nature, always refers, at least indirectly, to rational beings and has only them as its [ultimate] aim' (SL 4:275). What this last remark

\footnotetext{
${ }^{9}$ Adorno and Horkheimer (2002 [1944], p. 2).
} 
suggests is that acquiring (a degree of) mastery over the natural environment is at best a means to our final end, not the end itself. ${ }^{10}$

Having said that, I believe we still have the option of interpreting Control differently, and some things Kosch says point us in this direction. In fact Kosch says that dominion over everything only expresses the goal of our pure drive before its ethical redirection, when it is nothing more than the 'blind drive' Fichte speaks of in connection to evil. After its ethical redirection, however, what the pure drive seeks is that reason as such acquires independence from external limitations, including limitations imposed upon it by the natural environment. Following Kosch (2015), this would give us a new formula of our final end:

Independence: Our progress toward the final end of self-sufficiency is progress toward a state of affairs in which reason as such is free from external limitations of any kind.

On the basis of this new formula we could say that our ultimate goal is, not one of maximizing control over nature, but one of maximizing freedom from obstacles generally, human and non-human alike (Kosch 2015). I believe this would preserve Kosch's insight that making the natural environment a less inhospitable place for us to 'broaden the scope' of rational planning and deliberation is a valuable end, but it would avoid the mistake Wood points out of treating this activity as an end in itself. This would also throw light on a puzzling remark Fichte makes later in the Vocation essay which neither Kosch nor Wood cite, that 'unconditional control of the mechanism of nature' should not be produced for its own sake, but should be produced 'by all as one great free moral community' (BM 1:113).

\subsection{Second objection: the Indeterminacy Argument}

Untangling these exegetical issues is not so simple, however. For even if we grant the more charitable reading I have just proposed, the new

\footnotetext{
${ }^{10}$ The same point holds for what Fichte says near the end of the System of Ethics: 'If humanity is to make any considerable advance, then it must waste as little time and power as possible on mechanical work; nature must become mild, matter must become pliant, everything must become such that, with only a little effort, it will grant human beings what they need and the struggle against nature will no longer be such a pressing matter' (SL 4:362). When Fichte explains what this practice actually involves, he consistently speaks of 'directing' nature (as in the case of farmers, miners, and fishermen) and 'modifying' nature (as in the case of craftsmen, artisans, and factory workers) - but talk of 'controlling', 'dominating', or 'mastering' nature is absent (SL 4:345).
} 
formula we have before us remains vulnerable to a second objection. In Wood's view, any attempt to specify the content of our final end whether as Control or as Independence - is doomed to fail. This leads him to reject Kosch's interpretation outright, since the key to her interpretation, as we have seen, is that an action's goodness is measurable in terms of its tendency to promote a given end. As Wood explains, if we want to defend a consequentialist reading, we need a specific notion of our final end, one determinate enough for us to say, when evaluating a proposed course of action, that its consequences either maximize or fail to maximize the goal in view. But then we must ask: 'Do we have a determinate enough conception of absolute self-sufficiency to enable us to use "the end" in this consequentialist, calculative way?' (Wood 2016, p. 176). In opposition to Kosch, Wood answers that the System of Ethics does not tell us clearly enough what [Fichte] means by "absolute independence and self-sufficiency" to make this possible' (2016, p. 176). So, if we search Fichte's work 'for any claim of the form that a specific action is right or wrong because its consequences maximize self-sufficiency or independence, then', Wood warns us, 'we will search in vain' (2016, p. 177).

Wood's alternative reading therefore rests on the following claim:

Indeterminacy: The final end of self-sufficiency is necessarily indeterminate.

Now Wood acknowledges that readers might be tempted to find a less abstract formula of absolute self-sufficiency. But in light of Indeterminacy, he thinks that to convert Fichte's idea of our final end into 'something definite, which can be understood in calculative-consequentialist terms, is therefore necessarily to misinterpret him' (2016, p. 177, emphasis in original). Absolute self-sufficiency 'is supposed to be transcendentally absurd', he maintains (2016, p. 177, emphasis in original); 'No "helpful" consequentialist version of this end is even conceivable' (2016, p. 177).

What these statements bring to light, I think, is that Wood is committed to a strong version of his claim, based on what we may call:

The Strong Indeterminacy Argument

(1) The final end of self-sufficiency is necessarily indeterminate;

(2) Therefore, no articulation of this end is possible.

Yet it is worth pointing out that an idea can be indeterminate while still admitting of limited or partial articulations. And so we are at 
liberty to propose a weaker version of Wood's claim, based on what we may call:

The Weak Indeterminacy Argument

(1) The final end of self-sufficiency is necessarily indeterminate;

(2) Therefore, no full articulation of this end is possible.

Of course, if the Strong Indeterminacy Argument is sound, then there would be no room left for any teleological reading of Fichte's ethics, let alone the consequentialist one offered by Kosch. And that is precisely the conclusion Wood wants to defend in Chapters 5 and 6, that ' $[\mathrm{w}]$ hen it comes to material or teleological theories of ethics, Fichte wholly agrees with Kant in rejecting all such theories' (2016, p. 150, emphasis in original). What worries me, however, is that Wood appears to invoke the Weak Indeterminacy Argument later in his book - in Chapter 7 - when he suggests that we do have means of articulating our final end. According to Fichte, he writes, 'a society of rational beings relating to one another through free interaction is not merely a means to the ends of those who participate in it, but is its own end (ist selbst Zweck) (VBG 6:307). It is good in itself or for its own sake, not because we care about it, or even because we ought to care about it. This is as close as we are likely to come to having a conception of the independence or self-sufficiency of reason-the final human end' (2016, p. 223, emphasis added).

Remarks like this sit uneasily alongside the Strong Indeterminacy Argument. Once we concede that our final end admits of articulation, even a partial or limited one, the interpretive doorway Wood wanted to close in Chapters 5 and 6 - the doorway, that is, that leads to a teleological reading of Fichte's moral principle - opens anew. And as long as that doorway remains open, however slightly, we have no reason to accept Wood's thesis that Fichte is 'radically committed to deontology' (2016, p. 149). For the remainder of this paper I want to explore this possibility by sketching a new teleological reading, one that captures the deontological elements within Fichte's theory, but that does not turn into a form of calculative consequentialism.

\section{The deontological reading}

By way of preliminary, consider the following propositions:

(i) We are ignorant of consequences. For Fichte, judging the consequences of my actions would require an infinite faculty of 
understanding, a God-like perspective I of course lack as a finite rational being. He writes: 'Neither I nor any finite, and therefore in some way sensuous, being can at all comprehend how a mere pure will can have consequences and what these consequences might be like, since it is the essence of their finitude not to be able to comprehend that' (BM1:104). ${ }^{11}$ At any given moment all I can know with certainty is what my duty demands of me, without knowing 'how much good will follow from doing this and how this might happen' ( $S L$ 4:303).

(ii) We are only responsible for what we will. For Fichte, the consequences of my actions lie beyond my control, and so I am only responsible for what I will: 'I am responsible only for the will, which down here can, of course, aim only at the earthly purpose, but not for the consequences' (BM 1:95-96). My responsibility goes no further than the intention, motive, or disposition lying behind my deed. At any given moment, then, 'I ought to will in conformity with the law without regard to any intelligible and apparent purpose, without investigating whether anything other than the willing itself may result from my willing' ( $B M$ 1:100).

(iii) There is only an inner condition of moral worth. Given that my finitude prevents me from judging the consequences of my actions, and that I am only responsible for what I will, it follows that there is only an inner condition of moral worth, that I will from a feeling of contentious conviction. For Fichte, the very idea that an action could be 'good' simply because it meets an outer condition is contradictory: 'The aim is not merely that nothing should occur except what is good and in accordance with reason, that is, that legality alone should rule, but rather that this should occur freely, in consequence of the moral law' (SL 4:275). I am never permitted to violate my duty, without exceptions, 'even were I to believe that in doing this I would insure the salvation of the world' (SL 4:271; cf. GGW 5:182).

\footnotetext{
${ }^{11}$ Elsewhere Fichte goes so far as to say that true atheism 'consists in quibbling over the consequences of one's actions, in refusing to listen to the voice of one's conscience until one believes one has first foreseen the good consequences of the same. One thereby elevates one's judgment above God's, and makes oneself into God' ( $G G W$ 5:182).
} 
Interestingly, when Fichte proceeds to analyse our duties in greater detail in the System of Ethics, he sets up false counter-examples based on 'consequentialist'-style reasoning. In one case, we are to imagine that fulfilling our duty requires that we end our life, but then someone asks: Should you not save yourself if doing so would bring about or maximize good consequences? (SL 4:270). In another case, we are to imagine that fulfilling our duty requires that we preserve our life, but then someone asks: Should you not kill yourself if doing so would likewise bring about or maximize good consequences? (SL 4:270-71). Behind each question, Fichte points out, we find the 'same pretense that is normally employed to defend evil in general, namely, for the sake of the good that is supposed to arise from it' (SL 4:270). The same is true of the justification Fichte anticipates someone offering for robbery, which is worth quoting in full:

[Someone could object]: 'If what was taken from the person in question is not spoiled in any manner but is only used, then this does not interfere with the furthering of reason's end, which ought to be the ultimate goal of all our acting. Moreover, if, let us say, the new property owner were to employ it in a better manner than it would have been employed by the first person [from whom it was taken], then this advances reason's end. What if the person who took the property knew that the original owner would make some harmful use of it, whereas he himself intended to use it in a very praiseworthy way, for the greater glory of God and the greater service to his neighbors: would he not then, according to your own principles, be acting quite rightly?' (SL 4:293-94)

Without hesitation Fichte answers in the negative: 'I am commanded to promote the cause of the good only conditionally, that is, to the extent that it lies within my sphere and stands in my legitimate power, and I am absolutely forbidden to infringe upon the freedom of others' (SL 4:293-94). This expresses what I take to be the core of Fichte's version of deontology. Due to our finitude - our inability to predict the consequences of our actions, and our inability to control what lies beyond the will - it follows that 'everyone simply must do whatever his situation, his heart, and his insight order him to do - this, and nothing else' (SL 4:270). ${ }^{12}$

One would surely be hard pressed to find stricter deontological statements than the ones I have just quoted, and together they pose a formidable obstacle to the consequentialist reading discussed above.

${ }^{12}$ Fichte's version of deontology anticipates the ethical views of later continental thinkers. (Wood cites Kierkegaard, Lévinas, and Sartre, and we should add Derrida to his list.) 
But what I find noteworthy about these statements is that none of them rest, directly or indirectly, on the key claim of the Strong Indeterminacy Argument, the claim that no description of our final end is possible. All Fichte is saying is that at any given moment we must listen to our conscience carefully, and be sensitive to the particularities of our situation and to the limitations of what we can know and what we can control. And yet, the problems he exposes in the false counter-examples, all of which rest upon consequentialist-style reasoning, have nothing to do with the alleged mistake of specifying our final end. Instead, the problems have to do with overstepping the proper bounds of our finitude (by ascribing to ourselves a God-like faculty of understanding) or with misunderstanding the nature of moral worth (by thinking good ends justify evil means). To this extent, I think there is no disputing the claim that Fichte is a deontologist of sorts at the level of ordinary moral deliberation, since he unquestionably believes that an action's intrinsic worth lies in its motives rather than its effects. But then the crucial question becomes whether Fichte is also a deontologist at the level of philosophical moral reflection, and I find it less plausible that he is, for reasons I shall now explain.

\section{Leaving deontology behind}

When Fichte pauses to reflect upon the results of his theory of conscience in the System of Ethics, he writes: 'At that point we were quite unable to see how we could determine a priori what our duty is; we possessed no criterion at all for determining this, beyond the approval or disapproval of our conscience following the deed' (SL 4:209, emphasis in original). In this way, the theory of conscience served a very important function in the book: it 'guaranteed the practical applicability of the moral law' (SL 4:209). But Fichte reminds the reader that an equally important task still lies ahead. The criterion of conscience, he says, was sufficient 'for the purposes of acting in the course of life, but not for the purposes of science [Wissenschaft]' (SL 4:210). The question we must consider next, then, is whether there is an even higher principle - if not within consciousness, then at least within philosophy - a unitary ground of these feelings themselves' ( $S L$ 4:210). We must in turn shift frameworks, from that of ordinary deliberation (which goes no further than feelings) to that of philosophical reflection (which considers the ground of those feelings) (cf. SL 4:14). Only by proceeding in this way, Fichte explains, can we hope to 
show that the moral law is a principle with substantive content and real application to the empirical conditions of human life. But how does he propose to go about fulfilling this task?

This question is too vast for us to discuss fully here, but a few points are relevant for clarifying the root of my disagreement with Wood's deontological reading. When Fichte introduces the task of warranting the moral law in Part II of the System of Ethics, he offers a few illuminating remarks. First, he tells us that the task of supplying this warrant will amount to specifying the object of the moral law, by which he means the domain over which it has applicability. Secondly, he says that this object is strictly speaking only a practical idea (in the Kantian sense of the term), because it refers to something that 'ought' to be realized in the world - and this, he adds, 'immediately raises the question, What is this idea? Or, since ideas certainly cannot be grasped, how and in what way is this idea to be described?' ( $S L$ 4:65). When Fichte goes on to outline this reply, his choice of terms is unreservedly teleological. He says that we are to cognize things according to their 'purpose' or 'end' (Zweck) and that our cognition of the 'total purposiveness' (ganze Zweckmäßigkeit) of things gives the moral law its normative content (cf. SL 4:171, 210). At a philosophical level, then, we can investigate the principle underlying the feelings of conscience, and aided by teleological insight we can specify both the idea of 'what we ought to do' as well as the 'substrate in which we ought to approximate the realization of this idea' ( $S L$ 4:69-70, emphasis in original).

Wood highlights the importance of these claims too, but he does not draw the conclusion I wish to put forward here. The conclusion is that, while Fichte's ethics is deontological at the level of ordinary deliberation, it is teleological at the level of philosophical reflection. And it is teleological, I wish to argue, not as a form of consequentialism (according to which actions are measurable by their tendency to maximize a positive outcome), but rather as a form of perfectionism (according to which objects are measurable by their tendency to harmonize with a final end ${ }^{13}$ ). Support for this alternative interpretation comes from the fact that at the beginning of Part II, in the preliminary

\footnotetext{
${ }^{13}$ I am speaking of 'objects' in a technical sense here, as the original conditions of selfhood: our bodies, our minds, and our relations with others. Wood also points out that when Fichte employs 'means-ends reasoning in thinking about our duties', the 'means' in question 'are never actions or rules and policies of action, as Kosch's interpretation would require. These means are always things or persons' (2016, p. 177, emphasis in original). But in Wood's view, this still only gives Fichte's ethics a teleological 'flavor' (2016, p. 225).
} 
to $\S 4$, Fichte states that his subsequent argument must establish that the moral law refers to these objects and that it commands us 'to preserve them and to bring them to perfection' ( $S L 4: 75 ; \mathrm{cf} .150$ ). By the time Fichte gives us the details of this argument, in $\$ \$ 18-19$, the language of perfection (Vollendung, Vollkommenheit, or Vervollkommnung) is again prominent. When we cognize ourselves as embodied, intelligent, and social beings, he claims, we shall see that we are nothing more than instruments for the goal of reason's self-sufficiency. At this level, Fichte says, the moral law has binding force precisely as a law for us to cultivate and perfect the conditions of our selfhood - in short, to make ourselves more fit for the realization of reason (cf. $S L$ $4: 257,280){ }^{14}$

As we can begin to see, Fichte's brand of perfectionism is unique in comparison with the theories of Aristotle, Spinoza, or Wolff - for the simple reason that it is wholly 'agent-neutral' (Kosch 2015). ${ }^{15}$ This point of orientation also highlights an important issue, for it turns out that by 'reason as such' Fichte actually means the entire community of rational beings. And so, when he says that the perfection of our individual powers contributes to the self-sufficiency of reason, he means to claim that it contributes to the self-sufficiency of the entire community of which we are members. 'This ought to be the goal of all our thinking and acting', he writes, 'and even of our individual cultivation: our final end is not ourselves but everyone' (SL 4:253, emphasis added). This collective point of view also puts into focus the relationship Fichte conceives between human beings and non-rational nature. 'The proper object of the end of reason', he tells us later in the System of Ethics, 'is always the community of rational beings. One either acts immediately upon this community of rational beings, or else one acts upon nature for the sake of this community. - There is no efficacious acting upon nature simply for the sake of nature; the

\footnotetext{
${ }^{14}$ As Fichte writes: 'if the moral law wills something that is conditioned, namely, the realization through me of the dominion of reason outside of me, then it also wills the condition, namely, that I be a fit and capable means for this end [dass ich ein taugliches und geschicktes Mittel zu diesem Zwecke sey]' (SL 4:257). See Moggach (2011) for an illuminating account of 'post-Kantian perfectionism'.

${ }^{15}$ Brink (2003) has argued that Mill is a perfectionist in an agent-neutral sense. But we should emphasize that Mill's focus on happiness (as the state of our passivity) could not be further from Fichte's focus on self-sufficiency (as the state of our activity). This contrast was acknowledged long ago by George Morris, who wrote that 'J.S. Mill's greatest personal misfortune was that he was born the son of James Mill, and not of Johann Gottlieb Fichte' (1880:336). See also Hurka (1993) for a discussion of agent-neutral perfectionism in connection with Aristotle's ethics.
} 
ultimate end of acting efficaciously upon nature is always human beings' (SL 4:343). We are thus to perfect ourselves, and (at most) to modify the natural environment, for the sake of the greater social whole. This, for Fichte, constitutes each individual person's final vocation.

I should say once again that I have no particular attachment to the term 'perfectionism', although I do find it useful for capturing a substantive difference between Fichte's normative ethics and Kant's. ${ }^{16}$ If the interpretation I have sketched above is right, then Kant and Fichte share a deontological view of practical reasoning from the standpoint of ordinary deliberation: neither thinks we should judge our actions in light of their anticipated effects. Yet Kant's commitment to deontology runs deeper than this, I believe, since he also seeks to derive normative content from the moral law itself. This is most explicit in his second presentation of the categorical imperative, the Formula of Humanity, which states that we are to treat humanity, whether in ourselves or in others, as an end and never as a mere means ( $G$ 4:429). Here the Formula of Humanity is meant to give us concrete guidance in specifying the content of our duties, if only from the standpoint of ethical theorizing. But this is precisely what Fichte rejects, since he believes that the moral law is nothing more than a formal and empty principle: it presents us with a command to strive for self-sufficiency, without specifying the actions we ought to perform in fulfilling this command. For Fichte, as I have just noted, the solution lies in understanding the conditions of our selfhood embodiment, intelligence, and sociality - whose preservation and perfection, he claims, supply the moral law with normative content. In my view, this marks Fichte's decisive break with Kantian deontology at the level of philosophical reflection.

\footnotetext{
${ }^{16}$ More recently Wood has explained his choice of terms as follows: 'The reasons I would not label Fichte's ethics "perfectionist" have to do with the limitations normally associated with that term when it is used as a pernicious stereotype. A perfectionist ethics is normally assumed to aim at the perfection of the individual agent. It is assumed that this agent has a "nature" to be perfected, that we can have a determinate concept of this nature, and that everything the agent is or does can be determined by this nature and this concept' (2017). I agree that this label is unhelpful if we limit it to pre-Kantian views of a human 'nature' or 'essence'. But I do not see why we must restrict its usage to such views. Nor do I see a better label than 'perfectionism' for distinguishing Fichte's ethics from Kant's, especially in light of his effort to give normative content to the moral law from the conditions of our selfhood.
} 


\section{The perfectionist reading}

Where does this leave us? In his book, Wood emphasizes, quite rightly, that the social dimension of Fichte's theory informs his ideal of moral 'agreement' arrived at by free communication. According to this ideal, all human beings are 'partners in the communicative enterprise of rational mutual agreement on collective ends and universal principles' (2016, p. 207; cf. p. 211). Moreover, Wood concedes at one point that such communication is the best report we have of 'the independence and self-sufficiency of reason - the final human end' (2016, p. 223). I therefore find it puzzling that elsewhere Wood goes to such lengths in defending the Strong Indeterminacy Argument, claiming that our final end is by necessity 'indefinite' or even 'absurd', a concept describable only as 'that ideal (or even that transcendentally impossible) "whatever-it-might-be" toward which the (infinite) series of actions tends, whenever we think of each action as drawing nearer, approaching, or approximating it' (2016, p. 180). I do not see the textual support for this claim, since Fichte often presents the concept of our final end in terms of his social ideal. 'The necessary goal of all virtuous people', he writes, 'is unanimous agreement concerning the same practical conviction and concerning the uniformity of acting that ensues therefrom' ( $S L$ 4:236) - from which it follows, he says later on, 'that the overall end of the moral community as a whole is to produce unanimity concerning matters of morality. This is the ultimate end of all reciprocal interaction between moral beings' (SL 4:348, emphasis added). ${ }^{17}$

Along these lines, I also find it puzzling that Wood acknowledges the centrality of the concept of 'perfection' in Fichte's ethics without drawing what to my mind is the most straightforward conclusion, namely, that Fichte is a moral perfectionist. In Chapter 7, for example, Wood devotes a subsection to this theme titled 'Perfection: harmony, identity, equality', which starts by quoting Fichte's remark that there is only one thing in which everyone stands in 'complete agreement',

\footnotetext{
${ }^{17}$ There are certainly teleological and perfectionist themes already visible in Kant's ethics, as Guyer has documented (2014). But the extent to which Kant's ethics is a form of moral perfectionism is controversial. Interestingly, in an earlier work Wood draws a useful distinction between (a) the basic principle of an ethical theory and (b) the mode of reasoning an ethical theory advocates in deciding what to do (1999, p. 414, note 14). On these grounds, Wood argues that Kant is a deontologist with respect to (a) but a teleologist with respect to (b). I am unsure whether this distinction maps directly onto Fichte's ethics, since Fichte also speaks of (c) the domain over which a basic principle has applicability. Within these variables, I am inclined to say that Fichte is a deontologist with respect to (a) and (b), but a teleologist with respect to (c).
} 
that is, 'their ultimate goal - perfection' ( $V B G$ 6:310). He then goes on to contextualize this term with reference to Kant, for whom metaphysical perfection is 'the completeness of the many insofar as it constitutes a one' ( $K U$ 2:228), and for whom teleological perfection is 'the relation of the manifold in a thing to an end' (KU 5:346). Curiously, Wood does not hesitate to link perfection in these senses to the social ideal of our final end, writing that 'this concept of perfection identifies the human vocation in society (the end or purpose of society, what human beings are supposed to be in their relation to one another) with a relationship between them that accepts their differences, but co-ordinates different individuals into a harmonious unity' (2016, p. 220). But again, Wood does not draw the implication I think we should draw here: that Fichte believes we can give a limited yet fruitful articulation of our final end, and that he believes the social ideal of moral agreement is our best candidate.

To bring these reflections to a close, I shall very briefly suggest where this implication might lead us. In my view, what Wood says about the concept of perfection points us in the direction of the Weak Indeterminacy Argument, according to which the best candidate for articulating our final end is something like this:

Agreement: Our progress toward the final end of self-sufficiency is progress toward a state of affairs in which we freely agree in our practical convictions and ends, by way of on-going reciprocal communication.

Fichte himself hints at this formula when he writes that if all human beings could become perfect, and reach their highest and final goal, then they would all be fully equal to one another; they would be only One; a single subject' (VBG 6:310). ${ }^{18}$ Now, to become perfect in this sense - to become a single subject - no doubt presents every one of us with an infinite task, since it entails that we ought to strive for total harmony between all members of the moral community. Of course, this overarching goal need not concern us in the course of ordinary deliberation, where all we must do, Fichte tells us, is abide by the immediate feelings of our conscience, 'without doubting or quibbling

\footnotetext{
${ }^{18}$ This claim reappears in $\$ 18$ of the System of Ethics: 'Everyone ought to produce outside of himself absolute agreement or harmony with himself; he ought to produce such harmony in everything that is present for him, for he himself is free and independent only on the condition of such harmony' ( $S L$ 4:234). Fichte then goes on to argue that the agreement in question must be real, not merely ideal, and that the conditions of real agreement mandate the creation of a rational state, a rational church, and a rational university (SL 4:234-49).
} 
over the consequences' ( $G G W 5: 182$ ). But a concept of our final end in these terms is still necessary, Fichte thinks, if we want to make ethics an applicable science - and that is, I believe, the teleological basis of his moral theory. ${ }^{19}$

\section{References}

References to Fichte appear in the order of abbreviation, volume number, and page number from Fichtes Werke, edited by I. H. Fichte. Translations of Fichte (at times modified) come from The System of Ethics in Accordance with the Principles of the Wissenschaftslehre, edited by Daniel Breazeale and Günter Zöller. References to Kant appear in the order of abbreviation, volume number, and page number from the Akademie Ausgabe, Kants Gesammelte Schriften, edited by Königlich Preussische Akademie der Wissenschaften. Translations of Kant (at times modified) come from The Cambridge Edition of the Works of Immanuel Kant, edited by Paul Guyer and Allen Wood.

Adorno, Theodor and Horkheimer, Max 2002 [1944]: Dialectic of Enlightenment: Philosophical Fragments, trans. Jephcott Edmund. In Gunzelin Schmid Noerr (ed.), Stanford: Stanford University Press.

Breazeale, Daniel 2013: Thinking Through the Wissenschaftslehre: Themes From Fichte's Early Philosophy. Oxford: Oxford University Press.

Brink, David 2003: Perfectionism and the Common Good: Themes in T.H. Green. Oxford: Clarendon Press.

Coleridge, Samuel Taylor 1817 [1884]: Or, Biographical Sketches of My Literary Life and Opinions (Vol. III). In W.T.G. Shedd. (ed.), New York: Harper \& Brothers.

Fichte, J.G. Fichtes Werke (11 vols) 1971: In I. H. Fichte (ed.), Berlin: de Gruyter.

Fichte, J.G 2005: The System of Ethics in Accordance with the Principles of the Wissenschaftslehre, trans. Breazeale Daniel and Zöller Günter. Cambridge: Cambridge University Press.

Guyer, Paul 2014: 'Examples of Perfectionism'. The Journal of Aesthetic Education 48: pp. 5-27.

\footnotetext{
${ }^{19}$ An earlier version of this paper was presented at an author-meets-critics panel at the 2017 Central APA, and I would like to thank the audience members and Allen Wood for constructive feedback.
} 
Hegel, F.G.W 1977 [1801]: The Difference Between Fichte's and Schelling's System of Philosophy, trans. Cerf Walter and Harris H. S. Albany: Suny Press.

Hurka, Thomas 1993: Perfectionism. Oxford: Oxford University Press. Kant, Immanuel 1900: Kants gesammelte Schriften, ed. Akademie der Wissenschaften. Berlin: Georg Reimer (later Walter De Gruyter). 1992: The Cambridge Edition of the Works of Immanuel Kant. In Paul Guyer and Allen Wood (eds). Cambridge: Cambridge University Press.

Kosch, Michelle 2014: 'Practical Deliberation and the Voice of Conscience in Fichte's 1798 System of Ethics'. Philosophers' Imprint 14: pp. 1-16.

-2015: 'Agency and Self-Sufficiency in Fichte's Ethics'. Philosophy and Phenomenological Research 91: pp. 348-80.

Moggach, Douglas 2011: 'Post-Kantian Perfectionism'. In Douglas Moggach (ed.), Politics, Religion, and Art: Hegelian Debates. Evanston, IL: Northwestern University Press.

Morris, George Sylvester 1880: British Thought and Thinkers: Introductory Studies, Critical, Biographical, and Philosophical. Chicago: Griggs \& Co.

Neuhouser, Frederick 1990: Fichte's Theory of Subjectivity. Cambridge: Cambridge University Press.

Schopenhauer, Arthur 2009 [1841]. On the Basis of Morals. In Christopher Janaway (ed.), The Two Fundamental Problems of Ethics. Cambridge: Cambridge University Press.

Ware, Owen 2016: 'Fichte on Conscience'. Philosophy and Phenomenological Research: DOI: 10.1111/phpr.12286.

Wood, Allen 1999: Kant's Ethical Thought. New York: Cambridge University Press.

2007: Kantian Ethics. New York: Cambridge University Press.

- 2016: Fichte's Ethical Thought. Oxford: Oxford University Press.

- 2017: 'Reply to Ware and Moggach'. Author-meets-critic session, Central APA. 